\title{
Some observations on the cluster-forming Character of Staphylococcus.*
}

\author{
By Jun HiRANo** \\ 本野 潤：黄色葡萄状球菌の集塊性についての若干の觀察
}

Staphylococci are known to grow forming irregular cellular aggregates, occuring singly, in pairs, or in clusters consisting of various number of cells. This characteristic poses serious questions as to the reliability of usual methods of measuring bacterial growth such as plate-counting or nephelometric measurements. Apart from this problem, it is interesting to know with what frequencies the clusters having different numbers of cells occur in the culture and whether these frequencies may be subject to change during the course of culture. Experiments were carried out along this line with Staphylococcus aureus FDA $209 \mathrm{P}$ grown on ordinary broth (pH 7.0).

\section{Experimental Method}

The culture methods used were virtually the same as those reported previously ${ }^{1}$. Into a $5 \cdot \mathrm{ml}$ culture solution in a $20 \cdot \mathrm{ml}$ test-tube were inoculated 5 loops of bacterial suspension from a 18- to 24 -hour-old culture. The test-tube was shaken well and left to stand in a thermostat at $30^{\circ} \mathrm{C}$. Every 50 minutes after the inoculation, two loops of the culture solution were taken aseptically, and dropped each on a clean slide-glass. After adding a loopful of methylene-blue solution (M/500), the droplet was covered with a clean cover-glass and observed microscopically with oilimmersion (magnification=1500). The number of clusters having different numbers $(\nu)$ of bacterial cells was counted and recorded. Record was made for clusters whose $\nu$-values amounted to $1,2,3,4,5,6,7,8,9$, and $\geqq 10$. For large clusters having $\nu$-values of $\geqq 10$, a rough estimation of $\nu$ was made according to the size of the clusters, which, by preliminary exercise, allowed us to determine the $\nu$-values with the accuracy of about \pm 5 . The counting was effected successively for different microscopic fields, which, in order to avoid the repeated observation of one and the same field, were spatially separated in a regular manner as illustrated in Fig. 1.

* Papar delivered on Dec. 19th, 1949, at the Annual Meetings of the Scientific Researches of the Tokyo Institute of Technology.

Partially sponsored by the Grant for the Scientific Researches, Ministry of Education.

** Biochemical Laboratory, Tokyo Institute of Technology. 


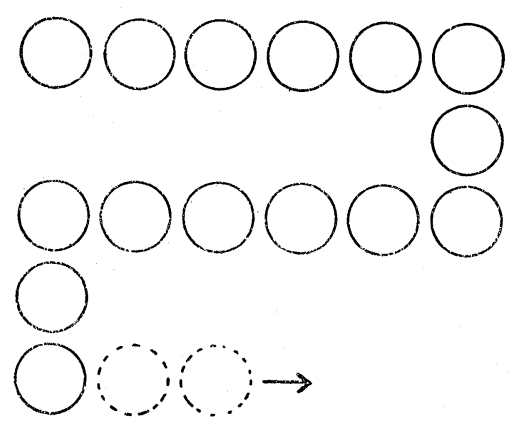

Fig. "Sampling" of microscopic fields for observation.

For each sample countings were made as many as possible during the interval (50 minutes) of successive samplings. Based on the records thus obtained, the following values were determined :

${ }_{t} \mathrm{H}_{\nu}$ : the number of clusters in a given sample, having the member-number of $\nu$, at the culture time $t$ (in minutes).

${ }_{t} \mathrm{M}_{\nu}\left(=\nu \cdot t \mathrm{H}_{\nu}\right)$ : the total number of bacteria (in the same sample as above), which are involved in clusters having the member-number $\nu$ at the culture time $t$.

${ }_{t} h_{\nu}$ : the ratio of ${ }_{t} \mathrm{H}_{\nu}$ to the total number of clusters $\left(\sum^{\nu}{ }_{t} \mathrm{H}_{\nu}\right)$.

${ }_{t} m_{\nu}$ : the ratio of ${ }_{t} \mathrm{M}_{\nu}$ to the total number of bacteria $\left(\sum^{\nu}{ }_{t} \mathrm{M}_{\nu}\right)$.

\section{Preliminary Tests}

In the above-described method one may suspect that the mounting of the droplet between the slide- and cover-glasses might possibly entail the break of some cluster into smaller pieces, so that the observation would yield more or less spurious results. To check this point, parallel experiments were run with duplicate samples, one by using the above-mentioned method and the other by observing the sample in a hanging drop. The results of observations made simultaneously are given in Table 1 , from which it may be seen that the two methods yielded essentially the same results.

Table 1. Comparison of the results obtained by two methods; (1) the hanging drop method, and (2) the method in which the sample was mounted between the slide and coverglasses.

The "Student's Test" was effected on the figures and the value " $F$ " computed.

\begin{tabular}{|c|l|rrrrrrrr|r|r|}
\hline \multicolumn{2}{|c|}{$v$} & 1 & 2 & 3 & 4 & 5 & 6 & 7 & $8 \leqq$ & Total \\
\hline \multirow{2}{*}{$50 \mathrm{H}_{\nu}$} & Method (1) & 51 & 160 & 23 & 40 & 13 & 5 & 4 & 5 & 301 \\
\cline { 2 - 9 } & Method (2) & 56 & 88 & 17 & 29 & 14 & 3 & 3 & 2 & 212 \\
\hline
\end{tabular}

$$
\mathrm{F}_{0}=1.48<\mathrm{F}=2.64
$$

Using the method described in the preceding paragraph, the reproducibility of the method was tested by running two observations with duplicate samples from the same culture, As may be seen from Table 2, the results obtained concurred with each other with only minor fluctuations. 
Table 2. Results obtained by parallel tests run simultaneously with duplicate samples from the same culture.

\begin{tabular}{|c|c|c|c|c|c|c|c|c|c|c|}
\hline \multicolumn{2}{|r|}{$\nu$} & 1 & 2 & 3 & 4 & 5 & 6 & 7 & $8 \leqq$ & Total \\
\hline \multirow{2}{*}{${ }_{50} \mathrm{H}_{\nu}$} & Test (1) & 26 & 43 & 10 & 13 & 4 & - & 1 & 2 & 99 \\
\hline & Test (2) & 30 & 45 & 7 & 16 & 10 & 3 & 2 & - & 113 \\
\hline
\end{tabular}

$\mathrm{F}_{\mathrm{l}}=1.17<\mathrm{F}=2.64$ (by "Student's Test")

\section{Results}

Observations carried out throughout the culture time from $t=50$ to $t=500$ minutes gave the results which are summarized in Table 3 as well as in Figs. 2 and 3.

The following facts have emerged from these observations :

(1) Except at the initial stage $(t=50)$ of the lag phase, the clusters with even number of $\nu(2,4,6$, and 8$)$ occur, in general, more frequently than those with odd numbers of $\nu(1,3,5$, and 7). (See Fig. 2) This finding may be interpreted as indicating that two daughter cells derived from one mother cell usually divide almost simultaneously.

(2) In the main, the percentages of the clusters with smaller $\nu$-values $(1,2,3$, and 4$)$ decrease with the progress of culture, while those with larger $\nu$-values $(6,7,8$, and $>9)$ show a tendency to increase, though sometimes after temporary decrease, as the age of culture advances. As a result, the percentage of bacteria belonging to larger clusters $(>9)$ increases re-

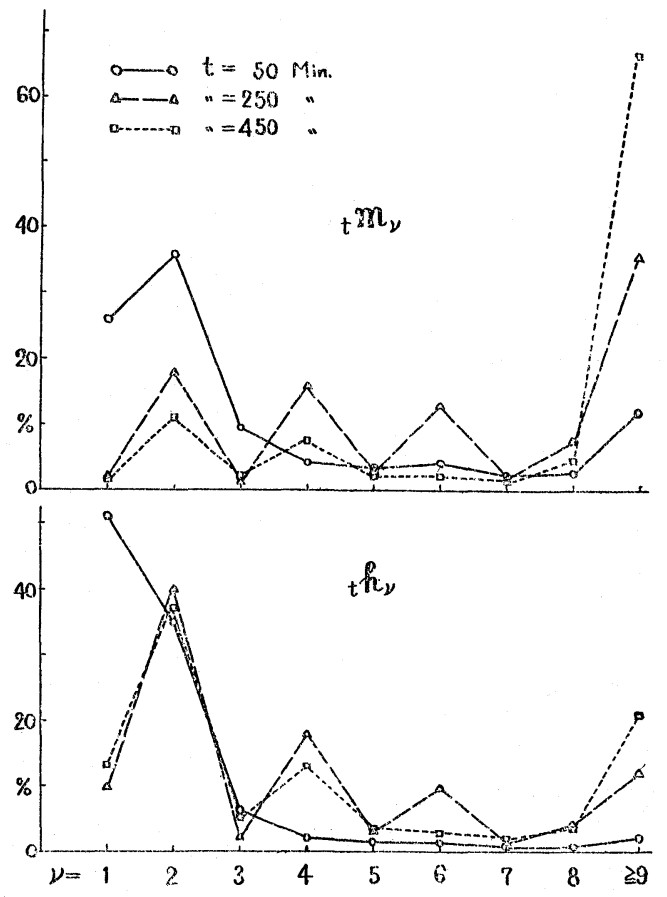

Fig. 2. Relative frequencies of clusters and bacteria with respect to the member-number $v$, at different culture times.

markably at later stages of culture. (See Fig. 3). In Fig. 4 is shown in what manner the mean number of bacteria in a cluster increased with time.

(3) Noteworthy is the fact that even at later stages of culture, the clusters with smaller $\nu$-values (especially those of $\nu=2$ ) were found in appreciable numbers. 

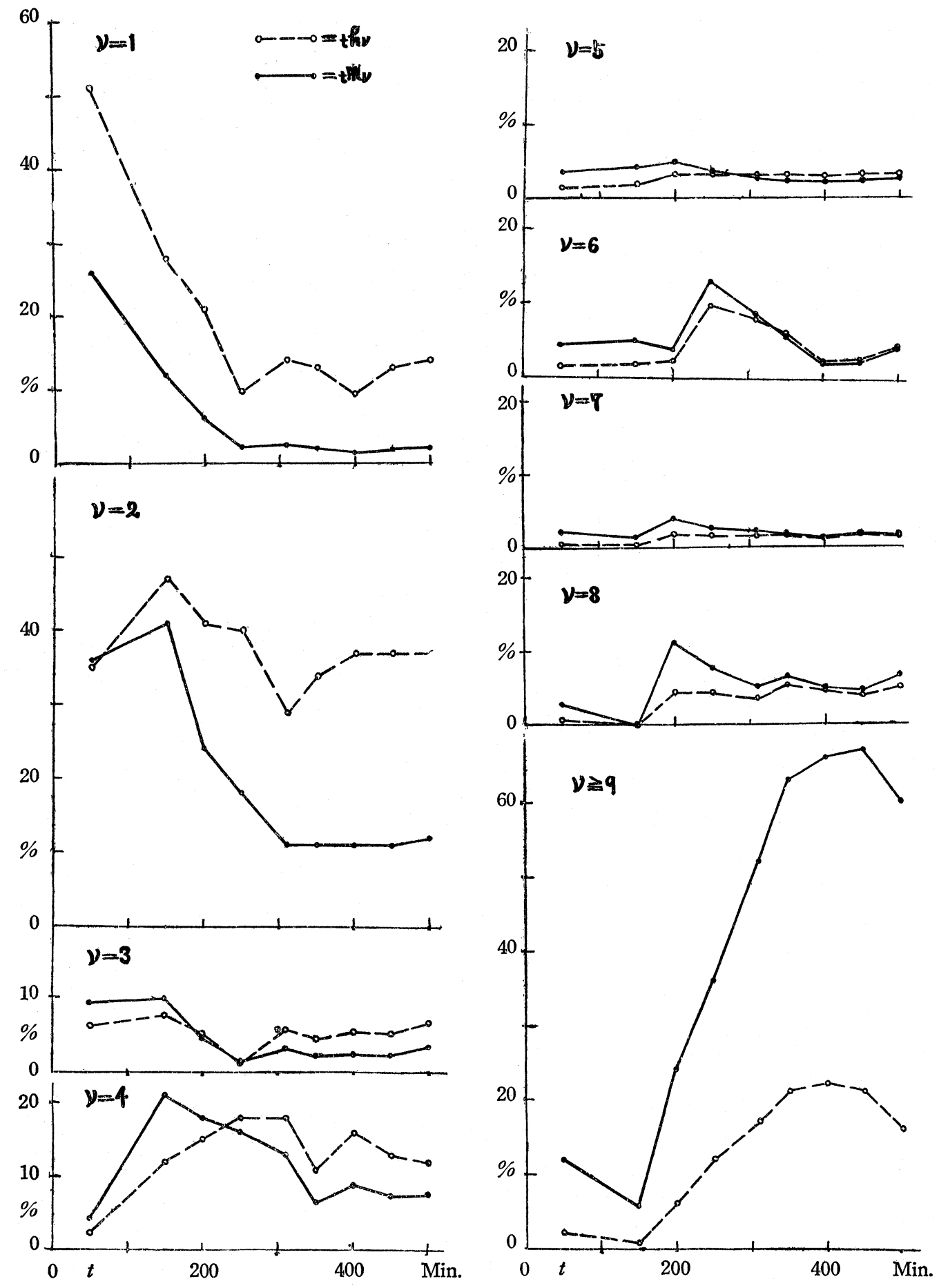

Fig. 3 The change, along with the culture-time, of the relative frequency of clusters with different $v$-values and of the relative frequency of bacteria belonging to them. 
Table 3. The frequency of clusters having different member number of bacteria $v$, and the fre-quency of bacteria belonging to differently populated clusters, and their changes during the course of culture.

\begin{tabular}{|c|c|c|c|c|c|c|c|c|c|c|c|c|}
\hline$t(\operatorname{Min})$. & & 1 & 2 & 3 & 4 & 5 & 6 & 7 & 8 & $9 \leqq$ & Total & $t \vec{\nu}$ \\
\hline \multirow{4}{*}{50} & ${ }_{t} \mathrm{H}_{\nu}$ & 74 & 51 & 9 & 3 & 2 & 2 & 1 & 1 & 3 & 146 & \\
\hline & ${ }_{t} \mathrm{M}_{\nu}$ & 74 & 102 & 27 & 12 & 10 & 12 & 7 & 8 & 35 & 287 & 1.97 \\
\hline & $t h_{\nu}(\%)$ & 51. & 35. & 6.2 & 2.1 & 1.4 & 1.4 & 0.7 & 0.7 & 2.1 & 100.6 & \\
\hline & ${ }_{t} m_{\nu}(\%)$ & 26. & 36. & 9.4 & 4.2 & 3.5 & 4.2 & 2.4 & 2.8 & 12 . & 100.5 & \\
\hline \multirow{4}{*}{100} & " & 17 & 14 & 2 & 4 & 1 & - & - & - & - & 38 & \\
\hline & " & 17 & 28 & 6 & 16 & 5 & - & - & - & - & 72 & 1.89 \\
\hline & $" \prime$ & & & & & & & & & & & \\
\hline & $" 1$ & & & & & & & & & & & \\
\hline \multirow{4}{*}{150} & "I & 57 & 98 & 16 & 25 & 4 & 4 & 1 & - & 2 & 207 & \\
\hline & " & 57 & 196 & 48 & 100 & 20 & 24 & 7 & - & 28 & 480 & 2.32 \\
\hline & " & 28. & 47. & $7: 7$ & I2. & 1.9 & 19 & 0.48 & - & 0.97 & 100. & \\
\hline & " & 12. & 41. & 10. & 21. & 4.2 & 5.0 & 1.5 & - & 5.8 & 100.5 & \\
\hline \multirow{4}{*}{200} & $" \prime$ & 76 & 147 & 19 & 55 & 12 & 8 & 7 & 16 & 22 & 362 & \\
\hline & "I & 76 & 294 & 57 & 220 & 60 & 48 & 49 & 128 & 300 & 1232 & 3.40 \\
\hline & $" \prime$ & 21 & 41. & 5.2 & 15. & 3.3 & 2.2 & 1.9 & 4.4 & 6.1 & 100.1 & \\
\hline & $" \prime$ & 6.2 & 24. & 4.6 & 18. & 4.9 & 3.9 & 4.0 & 11. & 24. & 100.6 & \\
\hline \multirow{4}{*}{250} & $" \prime$ & 19 & 76 & 4 & 34 & 6 & 19 & 3 & 8 & 22 & 191 & \\
\hline & $" \prime$ & 19 & 152 & 12 & 136 & 30 & 114 & 21 & 61 & 302 & 850 & 4.45 \\
\hline & $"$ & 9.9 & 40 & 2.1 & 18. & 3.1 & 9.9 & 1.6 & 4.2 & 12. & 100.8 & \\
\hline & " & 2.2 & 18. & 1.4 & 16. & 3.5 & 13. & 2.5 & 7.5 & 36. & 100.1 & \\
\hline \multirow{4}{*}{310} & "I & 40 & 84 & 17 & 51 & 9 & 23 & 5 & 10 & 48 & 287 & \\
\hline & $" 1$ & 40 & 168 & 51 & 204 & 45 & 138 & 35 & 80 & 840 & 1601 & 5.58 \\
\hline & $" 1$ & 14. & 29. & 5.9 & 18. & 3.1 & 8.0 & 1.7 & 3.5 & 17. & 100.2 & \\
\hline & $" 1$ & 2.5 & 11. & 3.2 & 13. & 2.8 & 8.6 & 2.2 & 5.0 & 52. & 100.3 & \\
\hline
\end{tabular}


(continued)

\begin{tabular}{|c|c|c|c|c|c|c|c|c|c|c|c|c|}
\hline${ }_{t}$ (Min.) & & 1 & 2 & 3 & 4 & 5 & 6 & 7 & 8 & $9 \leqq$ & Total & $t \bar{\nu}$ \\
\hline \multirow{4}{*}{350} & ${ }_{t} \mathrm{H}_{\nu}$ & 41 & $10 \bar{x}$ & 14 & 34 & 10 & 19 & 5 & 16 & 65 & 308 & \\
\hline & ${ }_{t} \mathrm{M}_{\nu}$ & 41 & 210 & 42 & 136 & 50 & 114 & 35 & 128 & 1290 & 2046 & 6.65 \\
\hline & $t^{h_{\nu}}(\%)$ & 13. & 34. & 4.5 & 11. & 3.2 & 6.2 & 1.6 & 5.2 & 21. & 99.7 & \\
\hline & ${ }_{t} m_{\nu}(\%)$ & 2.0 & 11. & 2.1 & 6.6 & 2.4 & 5.6 & 1.7 & 6.3 & 63. & 1007 & \\
\hline \multirow{4}{*}{400} & " & 31 & 121 & 18 & 51 & 10 & 8 & 4 & 14 & 72 & 329 & \\
\hline & "l & 31 & 242 & 54 & 204 & 50 & 48 & 28 & 112 & 1520 & 2289 & 6.96 \\
\hline & $"$ & 9.4 & 37. & 5.5 & 16. & 30. & 2.4 & 1.2 & 4.3 & 22. & 100.8 & \\
\hline & $" \prime$ & 1.4 & 11. & 2.4 & 8.9 & 2.2 & 2.1 & 1.2 & 4.9 & 66. & 100.1 & \\
\hline \multirow{4}{*}{450} & $" \prime$ & 51 & 144 & 20 & 51 & 13 & 11 & 7 & 15 & 82 & 394 & \\
\hline & "l & 51 & 288 & 60 & 204 & 65 & 66 & 49 & 120 & 1830 & 2733 & 6.94 \\
\hline & " & 13. & 37. & 5.1 & 13. & 3.3 & 2.8 & 1.8 & 3.8 & 21. & 100.8 & \\
\hline & $" \prime$ & 1.9 & 11. & 2,2 & 7.5 & 2.4 & 2.4 & 1.8 & 4.4 & 67. & 100.6 & \\
\hline \multirow{4}{*}{500} & $" 1$ & 44 & 112 & 21 & 36 & 10 & 14 & 4 & 15 & 50 & 306 & \\
\hline & " & 44 & 224 & 63 & 144 & 50 & 84 & 28 & 120 & 1120 & 1877 & 6.13 \\
\hline & "I & 14. & 37. & 6.9 & 12. & 3.3 & 4.6 & 1.3 & 4.9 & 16. & 100. & \\
\hline & "I & 2,1 & 12. & 3.4 & 7.7 & 2.7 & 4.5 & 1.5 & 6.4 & 60. & 100.3 & \\
\hline
\end{tabular}

This phenomenon may be interpreted in several ways. These clusters might have been in existence from earlier stages of culture and, owing to their small size, might have escaped from the observation until they attained certain recognizable dimension at later stages of culture.2) Or, they might have derived from clusters with larger numbers of $\nu$-values through incidental fracture caused by some external forces or by separation of cells induced by some internal causes.

Of great interest in this connection is the observation made by the author during the experiments reported in the previous paper.1) The test organism, Siaphylococcus aureus, is generally described as an immotile bacterium, and it is true that the cells of this bacterium are found to be devoid of cilia which are regarded as the motile organ of the bacterial cell. During the course of our study, however, it was several times observed that with the commencement of fission, the daughter cell or cells began to tremble, which often lasted even after the completion of the fission, with the result of the separation of the cell or cells from the mother 


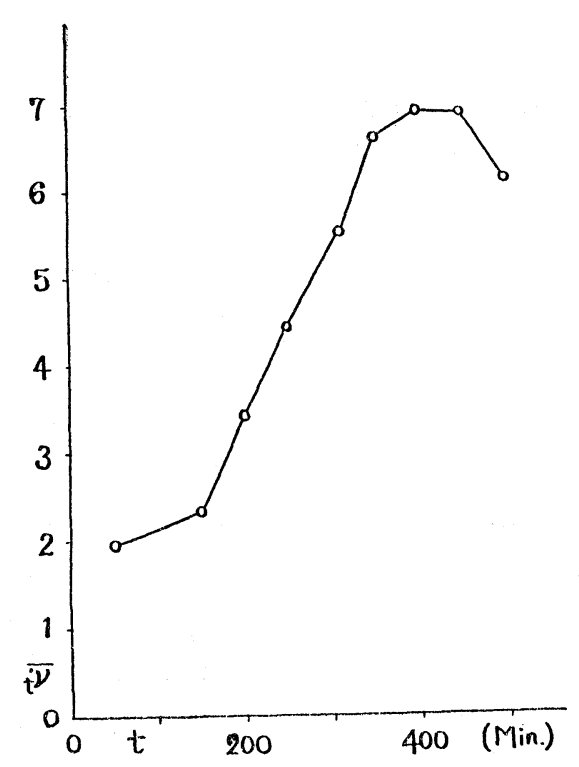

Fig. 4. The change with the culturetime of the mean number of bacteria in a cluster.

cluster. In some cases separation of cells by such a motion occurred without the fission usually directly preceding or concommitantly taking place with the separation. The trembling motion appeared sometimes so vivid that it looked as if the bacterium or the small cluster of daughter cells were making effort to part from the mother cluster. We do not know whether the trembling motion observed might have been brought about by those cells which happened to possess cilia or by some other causes, but at least it seems certain that some forces inherent in bacterial cells can cause the spontaneous separation of clusters into smaller pieces.

The author is very grateful for the kind guidances and encouragements given by Prof. Dr. H. TAmiYa and Dr. T. Yanagita, Plant Physiological and Microbiological Laboratories, Faculty of Science, Tokyo University; and Prof. Dr. A. TakamiYa, Biochemical Laboratory, Tokyo Institute of Technology.

\section{References}

1) Hirano, J.: Botan. Mag., Tokyo, 64, 133 (1951). 2) For example: Topley, W.W.C. \& G.S. Wilson: "The Principles of Bacteriology and Immunity, page $71 \mathrm{ff}$. Hinshelwood, N.: “The Chemical Kinetics of the Bacterial Cells,", 1946, Chap. X.

\section{和文 摘 要}

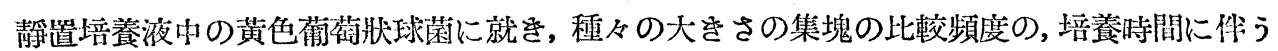
変化在觀察し, 1) 偶数凰集塊が大抵奇数個集塊より多いこと,2) 培養の進むにつれて, 大体, 大 きい集塊が多く存ること等急確かめ, 若干の考察在行つた。 